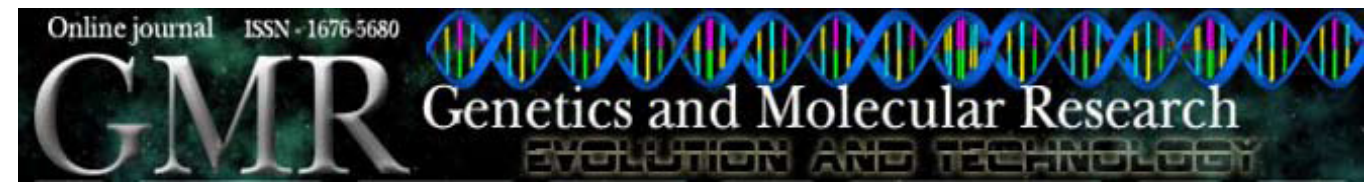

\title{
Occurrence of natural triploidy in Rhamdia quelen (Siluriformes, Heptapteridae)
}

\author{
J.R. Tsuda, V.P.O. de Moraes, L. Giuliano-Caetano and A.L. Dias \\ Departamento de Biologia Geral, CCB, \\ Universidade Estadual de Londrina, Londrina, PR, Brasil \\ Corresponding author: A.L. Dias \\ E-mail: anadias@uel.br
}

Genet. Mol. Res. 9 (3): 1929-1935 (2010)

Received June 2, 2010

Accepted July 17, 2010

Published September 28, 2010

DOI 10.4238/vol9-3gmr949

\begin{abstract}
Five specimens of Rhamdia quelen collected from the Lindóia Stream, PR, Brazil, were cytogenetically analyzed. The diploid chromosome number found was 58, including 30 metacentric, 16 submetacentric, 10 subtelocentric, and 2 acrocentric chromosomes. Supernumerary or B chromosomes, frequently observed in this fish group, were not detected. One of the individuals was triploid, with $3 n=87$. A silver-stained nucleolar organizer region was found on a pair of submetacentric chromosomes of the diploid specimens, and on three chromosomes of the triploid individual, confirming triploidy. Treatment with fluorochrome chromomycin $\mathrm{A}_{3}$ revealed fluorescent bands coincident with those of the silver-stained nucleolar organizer region, in both diploid and triploid individuals, showing that this is a GC-rich region. Heterochromatin distribution was visualized by the $\mathrm{C}$-banding technique, mainly in the terminal chromosome regions of the individuals and was also observed in the pericentromeric regions of some chromosomes and at both telomeres.
\end{abstract}

Key words: Fish cytogenetics; Polyploidy; Triploid fish 


\section{INTRODUCTION}

Several cases of polyploidy in lower vertebrates have already been reported; however, triploidy, the only form of polyploidy that has been described in Neotropical fish thus far, is becoming more frequent with the increase in the number of species and/or populations analyzed. The occurrence of triploidy has already been recorded for 16 species of fish belonging to different families, with greater frequency in some species of the genus Astyanax (Table 1).

\begin{tabular}{|c|c|c|c|c|c|}
\hline Species & $\begin{array}{l}\text { Total individuals } \\
\text { analyzed }\end{array}$ & $\begin{array}{l}\text { Total triploid } \\
\text { individuals }\end{array}$ & $2 n$ & $3 n$ & Reference \\
\hline \multicolumn{6}{|l|}{ Characidae } \\
\hline Astyanax schubarti & 21 & 1 & 36 & 54 & Morelli et al. (1983) \\
\hline Astyanax scabripinnis & $40(27 q / 13 \precsim)$ & 1 & 50 & $75+1 B$ & Maistro et al. (1994) \\
\hline Astyanax scabripinnis & $86\left(27 q / 59{ }^{\lambda}\right)$ & 1 & 50 & $75+2 B$ & Maistro et al. (1994) \\
\hline Astyanax scabripinnis & $64\left(529 / 22 \bigcirc^{\lambda}\right)$ & 19 & 50 & $75+2 B$ & Fauaz et al. (1994) \\
\hline Astyanax aff. Scabripinnis & $5(2+/ 3 \overbrace{}^{\lambda})$ & 19 & 48 & 72 & Malacrida et al. (2003) \\
\hline $\begin{array}{l}\text { Astyanax bockmanni (cited as } \\
\text { A. eigenmanniorum) }\end{array}$ & $30\left(15+15{ }^{\Uparrow}\right)$ & 1 우 and $1 \hat{0}$ & 50 & 75 & Fauaz et al. (1994) \\
\hline Astyanax sp D & $7(2+/ 5 \precsim)$ & 1 & 50 & 75 & Kantek et al. (2007) \\
\hline \multicolumn{6}{|l|}{ Crenuchidae } \\
\hline Characidium gomesi & $27\left(16+11 \delta^{\pi}\right)$ & 1 우 & $50(\mathrm{ZZW})$ & 75 & Centofante et al. (2001) \\
\hline \multicolumn{6}{|l|}{ Curimatidae } \\
\hline Curimata modesta & 10 & 1 & 54 & $81+1 B$ & Venere and Galetti Jr. (1985) \\
\hline \multicolumn{6}{|l|}{ Sternopygidae } \\
\hline Eigenmania $\mathrm{sp}$ & $6\left(3+/ 3 \bigcirc^{\pi}\right)$ & 1 & $31 / 32$ & 46 & Almeida-Toledo et al. (1985) \\
\hline \multicolumn{6}{|l|}{ Gymnotidae } \\
\hline Gymnotus carapo & $17(4+/ 10 \overbrace{}^{1} / 3 ?)$ & 1 & 54 & 81 & Fernandes-Matioli et al. (1998) \\
\hline \multicolumn{6}{|l|}{ Erythrinidae } \\
\hline Hoplerythrinus unitaeniatus & $22(15 \circ / 7 \delta)$ & $1+$ & 48 & 72 & Giuliano-Caetano and Bertollo (1990) \\
\hline \multicolumn{6}{|l|}{ Heptapteridae } \\
\hline Rhamdia sp & $13(7+/ 6 \gtrsim)$ & $1+$ & 58 & 87 & Garcia et al. (2003) \\
\hline Rhamdia quelen & 5 & 1 & 58 & 87 & Present study \\
\hline \multicolumn{6}{|l|}{ Trichomycteridae } \\
\hline Trichomycterus davisi & 50 & 1 & 54 & 81 & Borin et al. (2002) \\
\hline \multicolumn{6}{|l|}{ Anostomidae } \\
\hline Leporinus cf. elongatus & 28 & $1 \hat{\jmath}$ & $54(Z Z Z)$ & 81 & Molina et al. (2007) \\
\hline
\end{tabular}

In Curimata modesta (Venere and Galetti Jr., 1985) and Astyanax scabripinnis (Fauaz et al., 1994; Maistro et al., 1994), triploidy was accompanied by supernumerary or B chromosomes. Triploidy in Characidium gomesi (Centofante et al., 2001) and in Leporinus cf. elongatus (Molina et al., 2007) was even more interesting, since these species have differentiated sex chromosomes. In the first species, the triploid individual was a female with one $\mathrm{W}$ and two $\mathrm{Z}$ chromosomes, while in the second the triploid was a male with $3 \mathrm{Z}$ chromosomes.

The fertilization of a diploid oocyte by a haploid spermatozoon, combined with possible thermal shocks (Cuellar and Uyeno, 1972; Valenti, 1975), has been considered the most probable origin of these triploid individuals.

In the present study, a chromosome analysis of a Rhamdia quelen population was carried out, whereby the occurrence of natural triploidy was observed and recorded in this species.

\section{MATERIAL AND METHODS}

Five specimens of $R$. quelen collected in the Lindóia Stream, Paraná, Brazil, Tibagi 


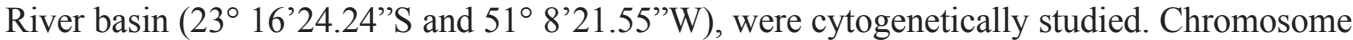
preparations were obtained from kidney cells by the direct method described by Bertollo et al. (1978) and from cultured lymphocytes following the method of Fenocchio and Bertollo (1988). The chromosomes were classified as metacentric (m), submetacentric (sm) and subtelocentric (st), according to arm ratio as proposed by Levan et al. (1964), and as acrocentric (a) with $r$ equal to or greater than 7. Chromosomes classified as metacentric, submetacentric and subtelocentric were considered as biarmed, and acrocentric ones as uniarmed, to determine the fundamental number (FN). Silver staining of the nucleolar organizer region (AgNOR) and C-banding were performed using the methods of Howell and Black (1980) and Sumner (1972), respectively. Chromomycin $\mathrm{A}_{3}\left(\mathrm{CMA}_{3}\right)$ staining followed Schweizer (1980).

\section{RESULTS AND DISCUSSION}

Four of the five individuals analyzed exhibited a diploid number equal to 58, which is the most frequently found in this genus. The karyotype formula showed $30 \mathrm{~m}, 16 \mathrm{sm}, 10 \mathrm{st}$, and 2a chromosomes, with an FN of 114 (Figure 1A). Although the occurrence of supernumerary or B chromosomes is common in the species studied, the presence of these chromosomes was not observed in this $R$. quelen population.

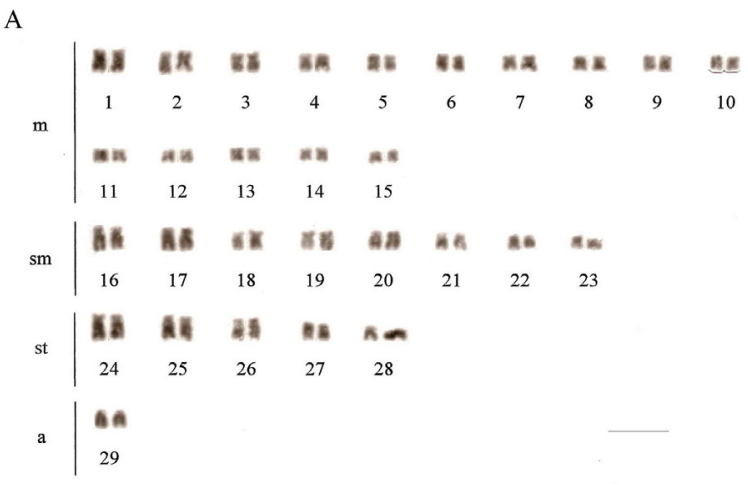

B

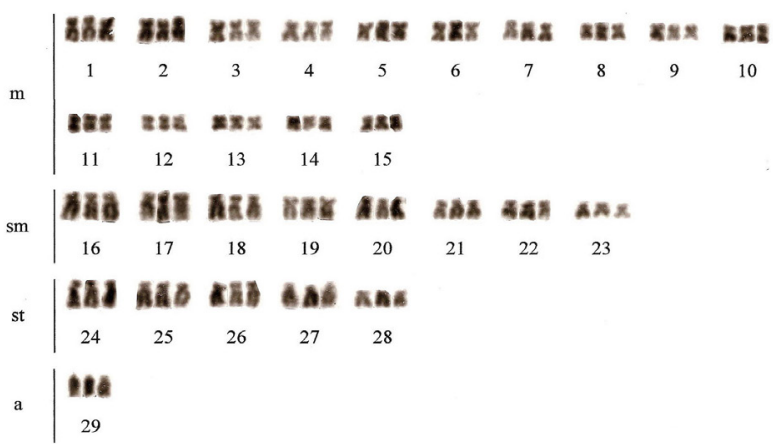

Figure 1. Karyotypes of Rhamdia quelen. A. Diploid individual. B. Triploid individual. $\mathrm{m}=$ metacentric; $\mathrm{sm}=$ submetacentric; $\mathrm{st}=$ subtelocentric; $\mathrm{a}=$ acrocentric. $\mathrm{Bar}=10 \mu \mathrm{m}$. 
One individual of $R$. quelen analyzed in the present study displayed $45 \mathrm{~m}, 21 \mathrm{sm}$, 15 st, and 6 a chromosomes, with a total of 87 , characterizing a natural triploid, and did not show the presence of B chromosomes (Figure 1B). This triploid displayed all the morphological characteristics of the species and did not show any difference when compared to the diploids. A case of triploidy in the genus Rhamdia has already been reported by Garcia et al. (2003) in one specimen of Rhamdia sp collected from the Grande Stream in Pindamonhangaba, SP, which also showed a karyotype number of $3 \mathrm{n}=87$ and a lack of B chromosomes, although such chromosomes were found to be present in the diploids.

Some hypotheses can explain the origin of natural triploids. Nevertheless, the most likely and most accepted is the fertilization of a diploid egg by a haploid sperm (Cuellar and Uyeno, 1972). The causes of non-reduced ovules may be related to possible thermal shocks and chemical agents during spawning (Romashov and Belyaeva, 1965; Al-Sabti et al., 1983). Fertilization is external in the majority of fish, with oocytes finishing the second meiotic division in the external medium and having a greater possibility of being affected by the environmental conditions compared to spermatozoa (Fauaz et al., 1994).

The individuals of $R$. quelen, the subject of this study, were collected from a region that suffers from degradation, especially correlated to the decomposition of organic matter and the absence of riparian vegetation, resulting from urban and agricultural occupation (Limberger and Corrêa, 2005). Such environmental disturbances may affect oocyte meiotic division and cause the formation of triploid individuals.

Silver impregnation in R. quelen from the Lindóia Stream demonstrated staining of the terminal portion of the short arm of a pair of submetacentric chromosomes (Figure 2a). AgNORs were detected in the terminal portion of the short arm of 3 submetacentric chromosomes of the triploid individual (Figure $2 b$ ), confirming triploidy and suggesting that there is no genetic inactivation of the triploid ribosomal cistrons, a hypothesis also supported by Maistro et al. (1994), Fernandes-Matioli et al. (1998), Borin et al. (2002), Garcia et al. (2003), and Molina et al. (2007). CMA fluorochrome staining produced fluorescent bands coincident with AgNORs, in the triploid as well as the diploid individuals (Figure 2c and d, respectively), showing that the DNA sequences of ribosomal genes are GC-base rich in both karyotypes.

C-banding analysis revealed the occurrence of heterochromatic bands, mainly in the chromosome terminal regions. Bands in the pericentromeric regions of some pairs and in both telomeres were also found, and some heterochromatic blocks were observed (Figure 2e and f), in both diploid and triploid individuals. Heterochromatin in the karyotypes of this group of fish was found basically distributed in terminal chromosomal regions of almost all chromosomes (Fenocchio et al., 2000; Swarça et al., 2003; Moraes et al., 2007). The distribution of heterochromatic staining in the terminal regions of both chromosome arms had already been described by Fenocchio and Bertollo (1990) in $R$. hilarii and by Garcia et al. (2003) in Rhamdia sp, as also observed in R. quelen in the present study.

In conclusion, the data presented herein show one more population of Rhamdia quelen that maintains the standard diploid number of the genus $(2 n=58)$ and disclose another case of triploidy, increasing the number of reported occurrences in Neotropical fish. 


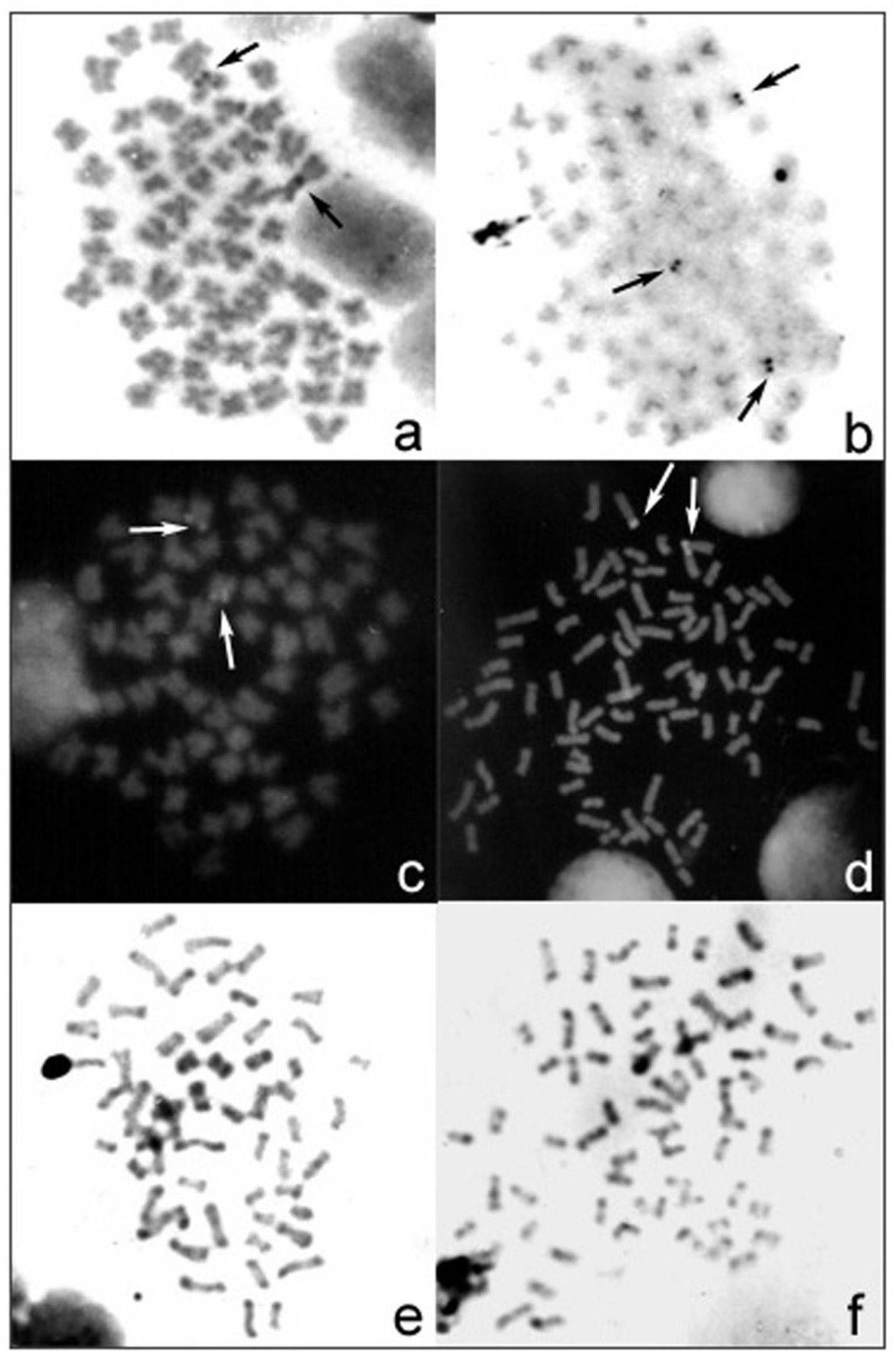

Figure 2. Metaphases of Rhamdia quelen. a.c.e. Diploid individual. b.d.f. Triploid individual. AgNOR (a,b); $\mathrm{CMA}_{3}(\mathrm{c}, \mathrm{d})$; C-banding (e,f). 


\section{ACKNOWLEDGMENTS}

Research supported by CAPES (Coordenação de Aperfeiçoamento de Pessoal de Nível Superior) and Fundação Araucária (Fundação Araucária de Apoio ao Desenvolvimento Científico e Tecnológico do Estado do Paraná).

\section{REFERENCES}

Almeida-Toledo LF, Foresti F and Toledo-Filho SA (1985). Spontaneous triploidy and NOR activity in Eigenmannia sp. (Pisces, Sternopygidae) from the Amazon basin. Genetica 66: 85-88.

Al-Sabti K, Kurelec B and Fijan N (1983). Spontaneous triploidy and tetraploidy in the common carp (Cyprinus carpio L.). Vet. Arch. 53: 217-223.

Bertollo LAC, Takahashi C and Moreira-Filho O (1978). Cytotaxonomic considerations on Hoplias lacerdae (Pisces, Erythrinidae). Rev. Bras. Genet. I: 103-120.

Borin LA, Martins-Santos IC and Oliveira C (2002). A natural triploid in Trichomycterus davisi (Siluriformes, Trichomycteridae): mitotic and meiotic characterization by chromosome banding and synaptonemal complex analyses. Genetica 115: 253-258.

Centofante L, Bertollo LAC and Moreira-Filho O (2001). Comparative cytogenetics among sympatric species of Characidium (Pisces, Characiformes). Diversity analysis with the description of a ZW sex chormosome system and natural triploidy. Caryologia 54: 253-260.

Cuellar O and Uyeno T (1972). Triploidy in rainbow trout. Cytogenetics 11: 508-515.

Fauaz G, Vicente VE and Moreira-Filho O (1994). Natural triploidy and B chromosomes in the Neotropical fish genus Astyanax (Characidae). Rev. Bras. Genet. 17: 157-163.

Fenocchio AS and Bertollo LAC (1988). A simple method for freshwater fish lymphocyte culture. Rev. Bras. Genet. 11: 847-852.

Fenocchio AS and Bertollo LAC (1990). Supernumerary chromosomes in a Rhamdia hilarii population (Pisces, Pimelodidae). Genetica 81: 193-198.

Fenocchio AS, Bertolo LA, Takahashi CS and Camacho JP (2000). B chromosomes in two fish species, genus Rhamdia (Siluriformes, Pimelodidae). Folia Biol. 48: 105-109.

Fernandes-Matioli FLC, Almeida-Toledo LF and Toledo-Filho SA (1998). Natural triploidy in the Neotropical species Gymnotus carapo (Pisces: Gymnotiformes). Caryologia 51: 319-322.

Garcia C, Moreira-Filho O, Bertollo LAC and Centofante L (2003). B chromosomes and natural triploidy in Rhamdia sp. (Pisces, Siluriformes, Heptapteridae). Cytologia 68: 403-411.

Giuliano-Caetano L and Bertollo LAC (1990). Karyotypic variability in Hoplerythrinus unitaeniatus (Pisces, Characiformes, Erythrinidae). II. Occurrence of natural triploidy. Rev. Bras. Genet. 13: 231-237.

Howell WM and Black DA (1980). Controlled silver-staining of nucleolus organizer regions with a protective colloidal developer: a 1-step method. Experientia 36: 1014-1015.

Kantek DLZ, Noleto RB, Fenocchio AS and Cestari MM (2007). Cytotaxonomy, heterochromatic polymorphism and natural triploidy of a species of Astyanax (Pisces, Characidae) endemic to the Iguaçu River basin. Braz. Arch. Biol. Technol. 50: 67-74.

Levan A, Fredga K and Sandberg AA (1964). Nomenclature for centromeric position on chromosome. Hereditas 52: 201-220.

Limberger L and Corrêa GT (2005). Diagnóstico ambiental do Ribeirão Lindóia (Londrina, PR): Aspectos físico-químico e bacteriológico. Rev. Elet. AGB/TL 2: 43-66.

Maistro EL, Dias AL, Foresti F, Oliveira C, et al. (1994). Natural triploidy in Astyanax scabripinnis (Pisces, Characidae) and simultaneous occurrence of macro B-chromosomes. Caryologia 47: 233-239.

Malacrida ACCP, Dias AL and Giuliano-Caetano L (2003). Natural triploidy in Astyanax aff. scabripinnis (Pisces, Characidae) of the Tibagi river bay-PR. Cytologia 68: 267-270.

Molina WF, Margarido VP and Galetti PM Jr (2007). Natural triploidy in Leporinus cf. elongatus bearing sex chromosomes. Genet. Mol. Biol. 30: 567-569.

Moraes VP, Cereali SS, Froehlich O and Dias AL (2007). Cytogenetic characterization of Rhamdia quelen (Siluriformes, Heptapteridae) from the Bodoquena Plateau, Mato Grosso do Sul, Brazil. Genet. Mol. Res. 6: 627-633.

Morelli S, Bertollo LAC and Moreira-Filho O (1983). Cytogenetic considerations on the genus Astyanax (Pisces, Characidae). II. Occurrence of natural triploidy. Caryologia 36: 245-250. 
Romashov DD and Belyaeva VN (1965). Induced polyploidy in Tilapia aurea (Steindachner) by means of temperature shock treatment. J. Fish Biol. 7: 519-528.

Schweizer D (1980). Simultaneous fluorescent staining of R bands and specific heterochromatic regions (DA-DAPI bands) in human chromosomes. Cytogenet. Cell Genet. 27: 190-193.

Sumner AT (1972). A simple technique for demonstrating centromeric heterochromatin. Exp. Cell Res. 75: 304-306.

Swarça AC, Fenocchio AS, Cestari MM and Dias AL (2003). Analysis of heterochromatin by combination of C-banding and CMA3 and DAPI staining in two fish species (Pimelodidae, Siluriformes). Genetica 119: 87-92.

Valenti RJ (1975). Induced polyploidy in Tilapia aurea (Steindachner) by means of temperature shock treatment. J. Fish Biol. 7: 519-528.

Venere PC and Galetti PM Jr (1985). Natural triploidy and chromosome B in the fish Curimata modesta (Curimatidae, Characiformes). Rev. Bras. Genet. VIII: 681-687. 